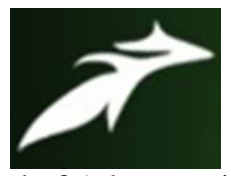

Gaurav Kumar et al, International Journal of Advances in Agricultural Science and Technology,

Vol.7 Issue.10, October-2020, pg. 6-10

ISSN: 2348-1358

Impact Factor: 6.057

NAAS Rating: 3.77

\title{
Beneficial Use of Vedic Indian Cow Dung
}

\section{Gaurav Kumar; Praveen Kumar Tiwari; Yashwant Atbhaiya; V.R. Upadhaya; Dileep Kumar Yadav \\ Ph.D. Scholars, National Dairy Research Institute, Karnal, Haryana - 132001}

\section{Introduction}

At the cow's name our western-influenced intellectuals sneer. The same scholars sneered at yoga in the first place. Doing pranayama at social events is now a trend. According to Vedas, cow essentially supplies five products that are considered as Panchgavya that have been used by humans for having several functional and therapeutic properties. The word Panchgavya comes from Sanskrit, meaning "Panch" means "five" and "gavya" means cow products.

The Panchgavya is a five-product blend. Which are: (i) Godugdha (cow-milk); (ii) Goghruta (ghee) (also classified as clarified butter); (iii) Gomutra (urine); (iv) Gomaya (dung)-deemed important as Gomutra; and (v) Dahi (curd). Three of these products (i.e. Godugdha, Gomutra, and Gomaya) are produced directly from the cow whereas two products (Goghruta and Dahi) are extracted from milk. Every Panchgavya product has its unique characteristics and qualities and these are widely used in health, agriculture and other fields. These have been commonly used in the treatment of different diseases since ancient times, since they have high medicinal qualities.

\section{Cow Dung}

The content of cow dung typically contributes to around 80 percent water and contains a matrix of undigested plant material abundant in nutrients, micro-organisms and their by-products. Cow dung microflora includes lots of bacilli, lactobacilli and cocci and other known and unrecognized fungi and yeasts. The approximate composition of the cow dung consists of crude fiber $40 \%$, carbohydrates $20 \%$, ash $10.5 \%$, crude protein $7 \%$, crude fat $4 \%$ and 


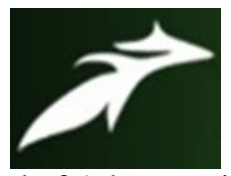

Gaurav Kumar et al, International Journal of Advances in Agricultural Science and Technology,

Vol.7 Issue.10, October-2020, pg. 6-10

ISSN: 2348-1358

Impact Factor: 6.057

NAAS Rating: 3.77

moisture $18.5 \%$ depends upon the feed and fodder given to the cow. $\mathrm{pH}$ of cow dung is in the range of 6.5-7.1.

Components of cow dung serve as germicidal, nourishing, give body light, killer and absorber of bad odour, virya vardhak (increase intelligence), rasayukta (moisturizer) and supremely pure and sacred. It has the natural property of curing skin diseases and diminishing blood toxins. Cow dung has antiseptic, toxic and thermal properties. Due to its extensive uses in different fields such as livestock, natural production, conservation of the atmosphere and medicinal applications, cow dung has been called a "Gold Mine".

Panchgavya can be really nice quality natural manure and bio-pesticides that have so many beneficial effects on livestock and sustainable cultivation. These bio-pesticides do not build up in the food chain and as such have no adverse consequences such as industrial pesticides. Also the cow dung can be used as alternative energy resources. The synthesis of urine and dung is a powerful renewable carbon supply, in the form of biogas, diesel and electricity. When cow dung is burned it balances ambient temperatures and destroys airborne germs.

\section{Fertilizer}

Now cow manure is actually being used as a fertilizer, causing the methane to be emitted into the atmosphere. Environmentalists concerned about regulating cattle dung methane pollution because that will be one of the main drivers of climate change. The volume of methane emitted into the environment during manure decomposition is more powerful in greenhouse gases than carbon dioxide. San Francisco invented a system that extracts and transforms methane from cow waste into biogas, which is nearly similar to natural gas. This can then be seen as a source of renewable energy and methane emissions won't be a problem.

Bio-fertilizer produced from cow dung has historically been used for centuries as organic fertilizer in Indian subcontinental farming, and is now one of the cheapest and harmless fertilizer source. Adding cow dung as a bio-fertilizer can restore soil mineral status improves soil fertility enhances plant defense to pests and promotes plant growth. This also provides other useful practices, including sulpho-oxidation and solubilization of phosphorus. When cow 


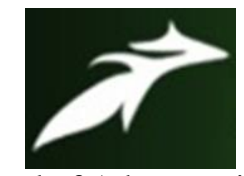

Gaurav Kumar et al, International Journal of Advances in Agricultural Science and Technology,

Vol.7 Issue.10, October-2020, pg. 6-10

ISSN: 2348-1358

Impact Factor: 6.057

NAAS Rating: 3.77

dung is used as a bio- fertilizer, it provides food that is free of chemical fertilizers and pesticides of any sort. Even it may be viewed as renewable carbon options.

Cow dung manure is the greatest effective crops nutrient because it is nitrogen-rich. Scientists also produced specific bio-fertilizers utilizing cow dung and urine and noticed that these biofertilizers were sprayed on crops reported for good growth and higher productivity than those in which bio- fertilizers developed from cow dung were sprayed. Cow dung as a bio-fertilizer don't cause any health hazards to the consumer as caused by chemical fertilizers; it improves overall growth of the crops, productivity and quality of crops and it also improves the health of the soil.

Manures from cow urine \& dung, makes the soil fertile, for yielding more nutrient fruits \& vegetables for healthy life. Cow dung is one of the fertilizer's main sources. African deserts became fertile with the use of cow dung. Application of cow dung for soil enrichment is an age- old farming tradition which was forgotten after chemical fertilizers were implemented. Nowadays citizens embrace sustainable and conventional agriculture and use cow dung as conventional manure rather than chemical manures.

\section{Low Nutrient Loss}

From the centuries, the cow dung cakes were used for cooking of foods. Cooking foods using cow dung cakes is the traditional practice which is followed in villages of our country, these have advantages like when food is cooked in cow dung cakes, the temperature never rises beyond a certain point, which prevents overheating and does not destroy the nutrients present in the food.

\section{Alternate Energy Source}

Cow dung can be the best valuable alternate source of energy as it can be used for biogas (methane) production and also generates electricity for consumer use. Biogas is a form of renewable energy source is used for cooking, lighting of homes and street lights. The selfcombustion engines can be driven by using these biogas for various uses like running a generator to produce electricity which can be used for various purposes. 


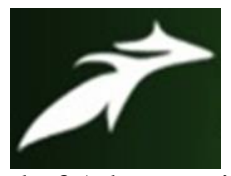

Gaurav Kumar et al, International Journal of Advances in Agricultural Science and Technology,

Vol.7 Issue.10, October-2020, pg. 6-10

ISSN: 2348-1358

Impact Factor: 6.057

NAAS Rating: 3.77

According to Japanese scientists Sakae Shibusawa at Tokyo University of Agriculture \& Technology, cattle dung is a new source of petrol (or gasolin), extracted from cow dung by applying high pressure and heat.

\section{Paper Making}

Paper is usually made by using wood as a raw material. The use of cow dung for paper making can be used as a best alternative to save wood. The high fibre content of cow dung enables people to make paper from the dung. The dung is washed to extract the fibres, which can then be pressed into paper on a screen.

\section{Container}

From the centuries, peoples used to store grains in huge earthen pots so as to keep insects, reptiles and other rodents away. By keeping in the containers made from cow dung, the grains can be stored for long time. Smoldering of cow dung cakes keeps away mosquitoes from the houses.

\section{Pollution Controller}

Mere presence of cows is a great contribution to the environment. India has approximately 30 crore cattle. Using their dung to produce biogas, approximately 6.0 crore ton of firewood can be saved every year. This would reduce deforestation to some extent and helps in environmental protection. We can reduce acid content in water by treating it with cow dung as it acts as a pH balancer. Hence, it can be said can say that cow dung has an important role in preserving environment.

Cow dung releases high amount of oxygen like some holy plants (eg. tulsi and peepal), which are used in sacrificial fires and havans. If one spoon of pure ghee is poured on the burning cow dung cakes (fuel) it produces one-ton oxygen that subsides the effect of poisonous gases. There is no other better method to remove pollution.

\section{Prevention from Radiations}

Ancient scripture stated that "Suryaketu" nerve (prominent hump) present in all indigenous cow however it is absent in exotic breeds (Jersey, Brown Swiss, Holstein, Belgian Blue etc). 


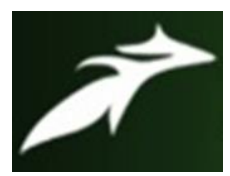

Gaurav Kumar et al, International Journal of Advances in Agricultural Science and Technology,

Vol.7 Issue.10, October-2020, pg. 6-10

ISSN: 2348-1358

Impact Factor: 6.057

NAAS Rating: 3.77

This nadi (vein) absorbs all the energies and radiations from sun, moon and all luminaries from universe and puts them in cow products like milk, urine, dung, ghee etc.

Cow dung is resistant to solar radiation as shown by several scientific studies. The studies proved that on applying thick layer of cow dung on the walls of the houses provide prevention against the gamma rays as these cow dungs can absorb such type of rays emitted from nuclear or solar emission. We have an example of "Bhopal Gas Tragedy" (in 1984), in which more than 20,000 people were killed and lacks of peoples were affected from the harmful chemicals and radiations which were released and emitted from the plant gas plant. Those living in cow dung coated walls houses were not affected. Atomic power centers in India and Russia even today working on cow dung to shield radiation.

Cow dung also used in making dhoop sticks by mixing fine powder of Nagarmutha, Ral, Lalchandan, Jatamachi, Kapoor kajuri and Ghee in cow dung. This dhoop sticks produces oxygen in the environment when burnt.

\section{Therapeutic Uses of Cow Dung}

Dairy farmers are five times less prone to develop lung cancer than the general population as reported by "new scientist magazine". Paste of cow dung and crushed neem leaves when applied on skin, it is good for boils and heat rashes. Cow dung is also a good alternative for toothpaste made from chemicals as to get rid form toothaches. Prof. G.E. Bea God, Italian scientist have done many experiments and proved that the fresh cow dung kills the germs of Malaria and T.B. It has been observed that smoke from ashes actually increases our eyelids to close and open so many times that lot of water from the eyes comes out which increases the vision life of a person to old age also. Cow dung is superior to other dung because it is antiseptic and has prophylactic (disease preventive) properties. It destroys micro-organisms that cause disease, fermentation and putrefaction. 